Feminist Social Work 


\section{Critical Texts in Social Work and the}

Welfare State

\section{General Editor: Peter Leonard}

Published

Pete Alcock and Phil Harris: Welfare LAW AND ORDER

Ragnhild Banton, Paul Clifford, Stephen Frosh, Julian Lousada and Joanna Rosenthall: THE POLITICS OF MENTAL HEALTH

Paul Corrigan and Peter Leonard: SOCIAL WORK PRACTICE UNDER CAPITALISM: A MARXIST APPROACH

Lena Dominelli and Eileen McLeod: FEMINIST SOCIAL WORK

Ian Gough: THE POLITICAL ECONOMY OF THE WELFARE STATE

Chris Jones: STATE SOCIAL WORK AND THE WORKING CLASS

Paul Joyce, Paul Corrigan and Mike Hayes: STRIKING OUT: TRADE UNIONISM IN SOCIAL WORK

Peter Leonard: PERSONALITY AND IDEOLOGY: TOWARDS A MATERIALIST UNDERSTANDING OF THE INDIVIDUAL

Chris Phillipson: CAPITALISM AND THE CONSTRUCTION OF OLD AGE

\section{Forthcoming}

Peter Leonard: A CRITICAL HISTORY OF SOCIAL WORK THEORY

Mike Oliver: THE POLITICS OF DISABLEMENT

Goran Therborn: WELFARE STATES AND ADVANCED CAPITALISM

\section{Series Standing Order}

If you would like to receive titles in this series as they are published, you can make use of our standing order facility. To place a standing order please contact your bookseller or, in case of difficulty, write to us at the address below with your name and address and the name of the series. Please state with which title you wish to begin your standing order. (If you live outside the United Kingdom we may not have the rights for your area, in which case we will forward your order to the publisher concerned.)

Customer Services Department, Macmillan Distribution Ltd Houndmills, Basingstoke, Hampshire, RG21 2XS, England. 


\title{
Feminist Social Work
}

\author{
Lena Dominelli and Eileen McLeod
}

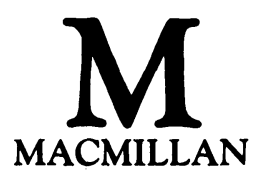


(C) Lena Dominelli and Eileen McLeod 1989

Foreword (C) Peter Leonard 1989

All rights reserved. No reproduction, copy or transmission of this publication may be made without written permission.

No paragraph of this publication may be reproduced, copied or transmitted save with written permission or in accordance with the provisions of the Copyright Act 1956 (as amended), or under the terms of any licence permitting limited copying issued by the Copyright Licensing Agency, 33-4 Alfred Place, London WC1E 7DP.

Any person who does any unauthorised act in relation to this publication may be liable to criminal prosecution and civil claims for damages.

First published 1989

$$
\begin{gathered}
\text { Published by } \\
\text { MACMILLAN EDUCATION LTD }
\end{gathered}
$$

Houndmills, Basingstoke, Hampshire RG21 2XS and London

Companies and representatives throughout the world

Distributed in the U.S.A. by New York University Press

British Library Cataloguing in Publication Data Dominelli, Lena

Feminist social work. - (Critical texts

in social work and the welfare state).

1. Great Britain. Welfare work. Feminist theories

I. Title II. McLeod, Eileen

III. Series

$361.3^{\prime} 01$

ISBN 978-0-333-35220-5

ISBN 978-1-349-19965-5 (eBook)

DOI 10.1007/978-1-349-19965-5 
To Maria Guiseppina, Connie, Maria and Rita (L.D.)

To Janyce, Nora, Rosemary and Viven (E.M.) 


\section{Contents}

Foreword by Peter Leonard

Acknowledgements

ix

xiii

Introduction

1 The Start of Feminist Social Work Intervention:

A Feminist Approach to Defining Social Problems

Redefining social problems from a feminist perspective - 'putting gender on the map'

Redefining social problems from a feminist perspective - an egalitarian process

The impact of defining and redefining social problems from a feminist perspective on professional social work practice

The further development of problem definition from a feminist perspective in social work and the gains for welfare

2 Feminist Community Work: The Nature and

Contribution of Feminist Campaigns and Networks

The identity of feminist campaigns and networks

The objectives and origins of feminist campaigns and networks

Developing egalitarian relations within feminist networks and campaigns

The impact of feminist campaigns and networks on society at large

Consolidating the work of feminist campaigns and networks

3 A Feminist Approach to Emotional Welfare: The Contribution of Feminist Therapy and Counselling

A theory and practice for women's emotional

well-being

The value of women's relationships

'Romantic love' and a loving alternative 
A feminist/anti-sexist approach to men's emotional welfare

Emotional liberation for children

4 Creating a Feminist Statutory Social Work 101 Introduction $\quad 101$

The contribution of radical social work and the Marxist critique 101

$\begin{array}{ll}\text { The development of feminist statutory social work } & 107\end{array}$

Characteristic features of feminist social work practice in statutory settings

Creating a feminist statutory social work

5 Creating Feminist Working Relations In and Through Social Work

Recognition of the problematic nature of women's material welfare and employment conditions

The promotion of women social workers' welfare as workers

The promotion of women social work clients and client groups' material welfare

Fostering awareness of the common material interests between women social workers and clients

The contribution of 'independent' feminist social work organisations

Underwriting the achievement of feminist working relations in social work

The benefits of feminist working relations for children's and men's welfare

6 Developing Together: a Feminist Political Presence and Feminist Social Work

Underwriting the future of feminist social work

The nature of a feminist presence in contemporary politics

The future of a feminist presence in politics and the contribution of feminist social work 


\section{Foreword}

When the series Critical Texts in Social Work and the Welfare State was launched in 1978 it was launched in 1978 it was situated within a particular discourse - that of Marxism. It was argued then that the foundations of a Left politics and practice in welfare must be based upon a Marxist political economy, a Marxist theory of the welfare state and a Marxist theory of interpersonal relations. The aim of the series was seen not as indulging in sectarian dogmatism but contributing to 'the development of the debate on the Left about the nature of the welfare state and the possibilities of socialist practice within it'. ${ }^{1}$

The ten years which have passed since these intellectual objectives were announced have been intensely traumatic years for both socialist practice and Marxist theory. Three factors in this trauma can easily be identified.

First, we have experienced the profound shift in class forces which marks triumph of the new Right in Western countries. This shift to the Right has had and continues to have a transforming effect upon welfare institutions and practices, and upon the debate within the Left generally. Ten years ago socialist discourse on welfare was situated within a critique of social democracy, its bureaucracies, its elitism, and its alienation from the working class. It took some time for the Left to realise that social democracy as we knew it was dead and buried, and that the radical neo-conservatism of this new era required far-reaching changes in socialist thinking and action.

Second, the politics of existing 'socialist' countries has ranged from disappointing failure to outright oppressive horror. There comes a point when it is increasingly difficult to continue a commitment to the grand project of socialism in the absence of any positive 
examples. Within eastern and central European countries, for example, where the language of Marxism has been pressed into the service of state dogma, progressive, socialist critiques of welfare have at this point to look elsewhere than to Marxist analysis for their frameworks, because Marxist discourse seems hopelessly debased through its service to oppression.

Third, and most important in relation to the publication of this particular volume in the series, are the deeply significant critiques of Marxism which have been articulated within wider progressive political forces and their organic intellectuals. Of these various critiques, it must be acknowledged that the most profound and farreaching have emerged from the women's movement and from feminist scholarship directed at the analysis of gender relations in every field of human activity. Although debates within feminism between the various tendencies that are represented within the broad movement have been politically divisive, all feminists agree on the centrality of gender relations to any analysis of the social order, its institutions and ideologies. Furthermore, feminist analysis claims to provide a more complete understanding of the politics of welfare than a Marxist interpretation is capable of, and most importantly, a more complete guide to practice within the welfare field.

Lena Dominelli and Eileen Mcleod's Feminist Social Work stands firmly and impressively in this growing tradition of critiques of Marxist theory and practice as part of its development of a feminist politics within every level of welfare. Although it is thoroughly critical of previous writing in the area of radical, socialist, social work practice, including all the relevant volumes in this series, it is most importantly practical, empirical and prescriptive in its approach. It demonstrates convincingly the outstanding virtue of the best feminist writing, a determination to give priority to political practice rather than abstract theorising

The authors of Feminist Social Work approach practice through an examination first of the definition of social problems and how a feminist perspective illuminates our understanding of the significance of gender in their construction. They then give an account of a range of feminist work in campaigns and in therapy before exploring the possibility of a feminist practice in the most recalcitrant of settings - that of statutory social work. They then turn to the working relationships which might be established among social 
workers on the basis of feminist principles. Finally, Lena Dominelli and Eileen McLeod write optimistically about the wider political presence of feminism as the context for the effective development of feminist social work.

Given its highly critical stance in relation to 'socialist' practice, where is this book located within the series? It has become increasingly evident in recent years that any simple pairing of feminism with socialism is exceptionally problematic and at this juncture impossible. ${ }^{2}$ When feminism enters into a dialogue with Marxism, it is bound to be sharply critical, unmasking and challenging in the most profound way possible, namely not only about what we see in the world (and what we fail to see) but also how we attempt to understand it. Feminists are right to argue that classical Marxism, at least, is inadequate as a basis for understanding the social world and our internalisations of it. Marxism, if it is to remain a dynamic and reflective theory and method has to be feminised, and undergo the thorough changes that this process implies. Certainly, no socialism is now conceivable which fails to address the issue of gender as central to any development of egalitarian and non-exploitative social relations. On its side, feminism also benefits from its discourse with Marxism; it must confront the core theory and practice of the socialist tradition if it is to pursue its own politics. This book makes its own valuable contribution to this discourse.

In a review of Linda Gordon's study of family violence in Boston 1880-1960, ${ }^{3}$ Kenneth Keniston raises the most important issue which confronts the dialogue between feminists and Marxists:

For Marx, the social relations of production were the Rosetta stone that unlocked the languages of ideology, consciousness, the state, economics, religion and historical change. Contemporary feminist scholarship suggests that even if gender is not the Rosetta stone, it is more than just another variable. Gender is the first, most unchanging and deepest of all the meanings attached to human beings. The achievement of scholars like Linda Gordon is to give gender a role in explanation equal to the role it plays in life. ${ }^{4}$

Whilst some feminists seem to see gender precisely as the Rosetta stone, those who interact closely with socialist thinking, as do 
Dominelli and McLeod, refrain from this final step, one which would subordinate all other social divisions, including class and race to the dominant imperative of gender. This book engages with this question of the relation of gender to other divisions and finds, unsurprisingly, the feminist analysis of this relation to be the most satisfactory. Their answers are likely to be subject to some debate among social workers; what will be welcomed by all readers are the careful spelling out of the implications of the feminist perspective for day-to-day practice in social work at every level of intervention.

McGill University

PETER LEONARD

Montreal

Notes

1. Corrigan, P. and Leonard, P. (1978) Social Work Practice Under Capitalism (London: Macmillan) Editor's Introduction.

2. Wilson, E. with Weir, A. (1978) Hidden Agenda (London: Tavistock Publications).

3. Gordon, L. (1988) Heroes of their Own Lives (New York: Viking).

4. Keniston, K. (1988) 'Wife Beating and the Rule of Thumb', New York Times Review of Books, 8 May. 


\section{Acknowledgements}

We warmly thank the women, children and men, too many to mention individually, who shared their experiences and opinions with us and continually provided us with fresh insights into our work as we were writing. We also want to express our deep gratitude for the practical support offered to us by all families, and close personal and academic friends. In particular, we wish to thank our readers - Sally Cherry, Mary Langan, and David Howe, for their helpful comments and constructive suggestions through the draft stage; Chris Woods for her efficient and speedy typing of the rough manuscript; David Whiteley whose willingness to do childminding, offer computer advice and endless loving support has been invaluable through the whole process of seeing this book through; and Anna McLeod for her understanding. Finally, we thank our friend and former colleague, Peter Leonard, for his support, advice, and commitment to seeing Feminist Social Work in print. 